УДК 78.01

DOI https://doi.org/10.31723/2524-0447-2020-31-2-13

\author{
Олександра Аркадіївна Сапсович \\ ORCID: 0000-0001-9175-1018 \\ кандидат мистецтвознавства,
}

в. о. доцента кафедри спеціального фортепіано

Одеської національної музичної академії імені А. В. Нежданової sapsovich@gmail.com

\title{
ПАМ'ЯТЬ ЯК АРХІВ ПРЕЦЕДЕНТНИХ СМИСЛІВ У ПРОЦЕСІ МУЗИЧНО-ВИКОНАВСЬКОЇ ІНТЕРПРЕТАЦІЇ (НА ПРИКЛАДІ ЧЕТВЕРТОГО КОНЦЕРТУ Л. БЕТХОВЕНА ТА ДО 250-РІЧЧЯ ВІД ДНЯ НАРОДЖЕННЯ КОМПОЗИТОРА)
}

Мета дослідження - простежити взаємодію процесів архівації в пам'яті «прецедентних смислів» $i$ створення музично-виконавської інтерпретації на прикладі практичного досвіду музиканта-виконавия. Методологія дослідження полягає в історичному екскурсі, репрезентації і структуруванні досвіду вибудовування і проживання алгоритму народження власного прочитання музичного тексту. Наукова новизна дослідження: показаний емпіричний, предметний шлях архівації (а також розархівації, релевантної осмисленню) прецедентних смислів музиканта з подальщим їх використанням. Викладено $і$ апробовано практичний алгоритм переходу з ролі виконавия до ролі інтерпретатора музичного тексту.

Висновки. Прецедентні смисли музиканта ми визначаємо як усвідомлену похідну емоційної пам'яті. Емоційна пам'ять - скарбничка пережитих емоцій, є основою прецедентних смислів, самі ж прецедентні смисли - це відрефлексовані й осмислені емоції (осмислені як у причинах, так $i$ в подальшому їх застосуванні у творчості). Отжке, розумісмо їх як такі, що виникають не тільки асоціативно, але і свідомо.

Системоутворюючими елементами кониепції народження самобутньої інтерпретації музичного тексту на базі феномена прецедентних смислів є:

- сприйняття та збережкення. Народження особистого художнього прочитання-осмислення виконуваної музики починається з запуску акумулятивного процесу: сприйняття і архівації (збереження в пам'яті) якомога більшого числа прецедентів (фактів) особистого зіткнення з будь-якими потенційно цінними джерелами інформації $i$ емоційного досвіду;

(C) Сапсович О. А., 2020 
- пошук, осмислення і зіставлення. Пошук здійснюється на основі акумульованого досвіду зіткнення з носіями інформації, за допомогою розархівації прецедентних смислів, що архівувалися раніше в пам'яті індивідуума. Осмислення відбувається в процесі пошуку і спровоковано ним. Зіставлення виступає як додатковий інструментарій переробки отриманих знань;

- народження творчого похідного прецедентних смислів, що виникає внаслідок реалізації вищеперелічених елементів $і$ виступає підгрунтям створення самобутньої інтерпретації.

Ключові слова: прецедентні смисли, емоційна пам'ять, виконання, інтерпретація, архівація, пошук, осмислення, творче похідне, школа.

Sapsovych Oleksandra Arkadiivna, Ph. D. in Art Studies, Associate Professor at the Special Piano Department of the Odesa National A. V. Nezhdanova Music Academy

Memory as an archive of precedent meanings in the process of musical interpretation (based on the example of Beethoven's fourth concerto and to the 250th anniversary of the composer's birth)

Purpose of the research: to trace the interaction of archiving processes in memory of "precedent meanings" and the creation of a musical performance interpretation using the example of the practical experience of a musicianperformer. The research methodology consists of a historical perspective; representation and structuring of the experience of building and living through algorithm for the birth of one's own reading of a musical text. The novelty of the research: an empirical, actual way of archiving (as well as unarchiving, relevant to comprehension) of the musician's precedent meanings with their further use is shown. A practical algorithm for the transition from the role of a performer to the role of an interpreter of a musical text is stated and tested. An algorithm for revealing the artistic image of a musical work by means of the synthesis of precedent meanings of a different order is presented.

Conclusions. We define the precedent meanings of a musician as a conscious derivative of emotional memory. Emotional memory, a piggy bank of experienced emotions, in this case, is the basis of precedent meanings, while the precedent meanings themselves are reflexive and meaningful emotions (meaningful both in reasons and in their further application in creativity). They arise not only associatively, but also consciously - in the understanding of the relationship of artistic images.

The system-forming elements of the concept of the birth of an original interpretation of a musical text based on the phenomenon of precedent meanings are:

- perception and preservation. The birth of personal artistic reading and comprehension of the music performed begins with the launch of an accumulative process: perception and archiving (storing in memory) many precedents (facts) of personal contact with any potentially valuable sources of information and emotional experience;

- search, comprehension and comparison. The search is carried out on the basis of the accumulated experience of contact with information carriers, 
by unarchiving precedent meanings previously archived in the memory of an individual. Comprehension occurs in the process of search and is provoked by it. Comparison acts as an additional tool for processing the knowledge gained;

- the birth of a creative derivative of precedent meanings. It arises as a result of the implementation of the above listed elements and acts as the basis for creating an original interpretation.

Key words: precedent meanings, memory, performance, interpretation, perception, archiving, unarchiving, search, comprehension, creative derivative, school.

Актуальність теми дослідження. Базова задача виконавця на практиці виявляється досить важкою: грамотно розібрати i почути фактуру, прочитати музичний текст (який $\epsilon$, безсумнівно, субстанцією значно ширшою, ніж фактура), оволодіти його ясністю, конструктивно-логічною об'єктивністю, розкрити його музичні «ієрогліфи» - осягнути символіку, ймовірно, виявивши автоцитування композитором всередині його ж музичної тканини. Нарешті, все це вміло і технічно відтворити. Ця «детективна» робота передбачає вивчення різноманіття творів кожного окремого автора, його музичної мови, поетики і на виході відіграє колосальну роль. Однак цей небагаторівневий процес відповідає лише реалізації ролі музиканта-виконавця, що втілює волю автора. Коли ж планка підіймається і мова заходить вже про музично-виконавську інтерпретацію, мають підключатися зовсім інші методи і «сервера». «Дивись крізь ноти - побачиш музику», говорив своїм учням професор М.А. Петров. I дійсно, шлях у це музичне «задзеркалля» $є$ процесом навіть більш складним і довгим, ніж проникнення у світ самої музичної «об'єктивності» (нотного тексту твору), хоча б тому, що включає в себе процес обов'язкового осягнення граней інших мистецтв, осягнення життя як такого i, нарешті, себе. Глибина i багатство цього «задзеркалля» прямо залежать від глибини внутрішнього світу того, хто хоче називатися інтерпретатором музики. Технологія цього переходу обговорюється в музикознавчій і мистецтвознавчій літературі з покоління в покоління. Ми ж спробуємо підійти до цієї проблеми крізь призму нашого емпіричного, іншими словами - практичного музикантського досвіду. Таким чином, важливим для розуміння процесу народження інтерпретації музичного твору $є$ розуміння процесу саме переходу музиканта з ролі виконавця в роль інтерпретатора художнього твору. 
Мета дослідження - простежити процес розкриття-переходу музиканта з ролі виконавця в роль інтерпретатора художнього твору.

Наукова новизна полягає в з'ясуванні алгоритму розкриття художнього образу музичного твору за допомогою синтезу прецедентних смислів різного порядку.

Виклад основного матеріалу. Для музикантів-практиків, як і для музикознавців, феномен інтерпретації часто йде рука об руку з явищем «школа», яке було сформульоване O.I. Самойленко як «придбане знання в купі з досвідом його розуміння» (Міжнародна науково-творча конференція «Явище школи в музичному виконавстві та музикознавстві: історія і сучасність», 30 листопада 2019 р.).

Розвиваючи це формулювання, розглянемо першу частину цієї конструкції - «придбане знання» в двох ракурсах: з одного боку, з позиції запам'ятовування певних смислів, що транслюються вчителем учневі, а з іншого - пізнання і засвоєння матеріалу за допомогою отримання особистого досвіду переживання. У першому випадку принципово важливий прецедент вербальної передачі інформації, збереженої або архівованої реципієнтом, у другому - прецедент індивідуального знайомства 3 тим чи іншим джерелом даних вже без посередників.

Поняття «прецедент» - «випадок або подія, яка мала місце в минулому і служить прикладом або підставою для подальших дій в сьогоденні» [8] - переносимо в простір мистецтва як факт емоційного знайомства художника з явищем або подією. Усвідомлення і осмислення сенсу цього прецеденту продукує виникнення «прецедентних смислів» - зазубрин на свідомості музиканта-художника, без яких неможливо таке важливе «друге народження» твору. «Прецедентні смисли музиканта», таким чином, ми визначаємо як усвідомлену похідну емоційної пам'яті, тобто відрефлексовані й осмислені емоції (осмислені як у причинах, так і в подальшому їх застосуванні в творчості).

Шо стосується другої частини визначення поняття «школа», тобто «досвіду розуміння», а також, за О.I. Самойленко, - «особистісного змісту» [10, с. 71], то тут важливим критерієм аналізу виступає час. Час як критерій істинності пізнання. Час має надважливу властивість, яку ми б охарактеризували як «позитивне забування». По суті, «позитивному забуванню» відповідає диференціація, або фільтрація знання, критичне осмислення, родинне інтерпретації. I тут ми впри- 
тул підходимо до кореляції явищ «школа» і «інтерпретація». Невипадково музиканти часто проводили паралель між цими двома сферами - не в останню чергу тому, що і в основі одної, і в основі другої лежить таке поняття, як традиція. Як часто ми чуємо або використовуємо усталений вираз «традиція виконання», або навіть парадоксальне - «традиція інтерпретації». Тут, правда, треба ввести важливе уточнення цих категорій. Розберемо їх послідовно.

Музикант-виконавець розуміється нами, перш за все, як втілювач музичного тексту. C.I. Савшинський звертає увагу на три категорії позначень, які виступають непорушною мірою реалізації цієї функції: перша - це ноти, що позначають висоту і тривалість їх звучання, паузи; друга - широке розмаїття графічних позначень; третя - все багатство словесних визначень [9, с. 25]. Савшинський також зазначає, що «зміст музичного твору не вичерпується звуковою даністю. До нього відноситься і все те, що ми знаємо про нього, що розкриває теоретичний аналіз його конструктивних властивостей. Його доповнює зіставлення з іншими творами того ж автора, характеристика творчості композитора і багато іншого» [9, с. 6]. Зазначимо, що останнє своєю чергою реалізується артистом за допомогою того дидактичного інструментарію, який дається саме теорією музики. Однак, на думку Л.С. Виготського, «для сприйняття мистецтва [а без сприйняття немислимо подальше відтворення] недостатньо просто щиро пережити те почуття, яке володіло автором, недостатньо розібратися і в структурі самого твору - необхідно ще творчо подолати своє власне почуття, знайти його катарсис, i лише тоді дія мистецтва позначиться сповна» [2, с. 315].

Тому, в жодному разі не минаючи, але спираючись на перелічені С.I. Савшинським дані об'єктивного музичного тексту, артист, пропустивши крізь призму свого «Я» прочитані і усвідомлені символи, залишені композитором на папері, вже перетворюється з виконавця на інтерпретатора музичного тексту. Але що є та «призма власного "Я"», про яку ми часто чуємо? Як це «Я» формується? Тут на авансцену виходить феномен пам'яті. І якщо в разі реалізації тієї самої ролі виконавця особливої ваги набуває пам'ять фізична - слухова, зорова, кінестетична, а також конструктивно-логічна, то для реалізації як інтерпретатора необхідна пам'ять емоційна, що являє собою надзвичайно поліфонічне явище. Починають 
діяти індивідуальні «сервера» пам'яті музиканта - надзвичайно продуктивний простір, який шукаючий музичний інтелект використовує на повну силу, щоб відбулося вже друге народження музичного полотна. Що ж є цей простір, з якого черпаються знахідки? Простір, заповненість якого, зрештою, і відрізняє одухотворене, незабутнє і самобутнє прочитання-інтерпретацію від «простого» промовляння нот? Для того, щоб розібратися і відповісти на це питання в практичній площині, звернемося до предмета нашого дослідження і нашого ігрового досвіду, пов'язаного з ним. Йтиметься про Концерт Л. Бетховена Соль мажор, ор. 58.

Четвертий концерт Бетховена - незаперечний шедевр, на долю якого, проте, випали певні труднощі, пов’язані з моментом його першого народження на публіці. Написаний у першій декаді XIX століття (ескізи датовані 1805 роком, видання належить до 1808 році), він був виконаний автором спочатку за рукописом у палаці князя Лобковіца, а потім на його ж авторській академії 22 грудня 1808 року. Бетховен не припускав сам виконувати намічений до відкритої прем'єрі Четвертий концерт через ослаблення слуху і звернувся до кількох відомих на той час піаністів, які разом із тим один за іншим відмовилися від цієї привілеї, чи то через недостатність часу на розучування партії, чи то через деяке суб'єктивне несхвалення нового твору. Тоді Бетховену не залишалося нічого іншого, як самому показати своє творіння. Це був його останній публічний піаністичний виступ. Як зазначає М.С. Друскін, критик Рейхардт знайшов концерт надзвичайно важким, а у виконанні Бетховена підкреслював «дивовижну досконалість і грандіозну віртуозність». Рейхардт писав далі: «Adagio - чудову частину з красивою витриманою мелодією - він [Бетховен] справді співав на своєму інструменті з почуттям глибокої меланхолії» [3].

Саме ця друга частина i $є$ предметом нашого особливого інтересу. Приголомшуючий контраст крайніх частин концертного циклу 3 його серединною частиною, як правило, написаною в спокійному русі, для жанру самого концерту (як і сонати) - справа звична. Однак саме Л. Бетховен, являючи своєю творчістю апогей розвитку жанру класичної фортепіанної сонати загалом, довів форму останньої до стану зразка. Ця ж якість в не меншому ступені відбивається і на його концертах. Щоб наголосити на тому, яка прірва розділяє образ- 
ний лад і стан, що панують у контрастних частинах сонат i концертів Л. Бетховена, згадаємо слова Ф. Ліста, сказані ним колись про другу частину 14-ї сонати: «Квітка між двох безодень». I хоча ця характеристика не охоплює всю драматургію тричастинних циклів Бетховена, вона акцентує полярність, закладену в них композитором.

Отже, Andante con moto [1] не просто написано в паралельній тональності (мі мінор щодо основного соль мажору), воно не просто з першої миті занурює нас у неймовірно далекий від тонусу першої частини модус, але, що сприймається ще гостріше, після прочитання кількох сторінок партитури, на яких розташовується ця частина, фінал, що настає слідом, здається вже неправдоподібно безтурботним, занадто легковажним, мало не поверхневим, «незручно» усміхненим. Фарби, нанесені на полотно автором у другій частині, як здається, не залишають місця для «до-мажорної радості», а саме в до мажорі написаний рефрен фінального рондо.

На думку М.С. Друскіна, з яким важко не погодитися, ця частина - одне з чудових творінь бетховенського генія. Її розміри не великі. Але експресивна виразність діалогів tutti i solo вкрай загострена: унісони струнних звучать у глибоких басах forte, staccato, пунктирному ритмі непохитного маршу; фортепіано відповідає їм м'яко, piano, legato, витриманими акордами в середньому і високому, співучому регістрі. Дослідник зазначає, що, за словами друзів Бетховена, коли створювалася ця частина, він був натхненний античним сказанням про Орфея, який співом своїм приборкує сили пекла: гнівні фурії намагалися не допустити його в підземне царство, де тужила Еврідіка - кохана міфічного співця. Виникали й інші програмні асоціації [3].

Зупинимося на «Оповіді про Орфея» та інших програмних асоиіаціях. Образ Орфея, звичайно, є, важливою зачіпкою, особливо, якщо авторитетний дослідник, яким є М.С. Друскін, спирається у своєму описі цієї частини концерту на спогади сучасників і друзів композитора. Безумовно, виконавець має знати, що надихало і хвилювало творця в момент створення їм музичного твору (а тут ми про це маємо інформацію не зі слів композитора, а з припущень його друзів). Однак, щоб відбувся інтерпретатор, потрібно піти далі і зануритися в ту бездонну нішу, натяк на яку дає власне Друскін. Реалізацією (а точніше початком реалізаціі) саме цих інших програм- 
них асоціацій, для нашого особистого виконавського досвіду, став епізод із репетиції цього концерту піаністом, чиє ім'я для музикантів усього світу, а особливо піаністів - знакове.

На початку 2000-х років в Одесу Четвертий концерт Л. Бетховена привіз Народний артист СРСР М. Петров - піаніст грандіозного масштабу. Концерт він готувався виконувати на сцені Великого залу Одеської філармонії з Національним Одеським філармонічним оркестром під керуванням Х. Ерла. На репетиції ніяк не йшла саме друга частина, що представляє собою емоційний остов усього концертного циклу. Соліст був не задоволений діалогом з оркестром (а саме на діалозі оркестрового tutti i піаністичного solo вона і збудована цілком) і в якусь хвилину перервав виконання, повернувся до оркестрантів і сказав фразу, яка відразу розставила всі акценти на свої місця: «Ця частина - ні що інше, як діалог Бога і маленької людини. Піаніст - це «людина». Оркестр у цьому діалозі «Бог». Грайте так». Як буває саме з істинними художниками, лише пара штрихів здатна вдихнути нове життя у витвір мистецтва. Так сталося і тоді. Оркестр змінився і звучання з вельми формального знайшло картинний сенс - з'явилася натхненність. Уже після репетиції, коли маестро Петрова запитали, про яку ж людині мова - хто ж говорив із Богом, піаніст, посміхнувшись очима, відповів одним словом: «Мойсей».

Через кілька років цей концерт став вже частиною нашого концертного репертуару. При цьому протягом довгого часу (мало місце повернення до цього концерту знову і знову, 3 різними оркестрами і диригентами) друга частина непереборно гралась нами саме про цей діалог - маленької людини і Бога. Практикувалася гра по вже заданій колії. З'являлося i, не знаходячи відповіді, зависало питання: «Чому саме Мойсей?» Чому тоді не Авраам, або, наприклад, Ной? Але якщо і Мойсей - як предметно лягає цей образ у формат музичної фактури цієї частини в соліста-піаніста? Десятки разів перегравалась і нами партія соліста, щоб зловити щось, що постійно вислизає. Нереалізованим і тому залишаючим почуття занепокоєння було питання візуалізації, деякої театралізації всієї музичної тканини.

Рішення, що приголомшує своєю очевидністю і односкладовістю, прийшло осяянням під час чергового сеансу багаторазового «проспівування» $\mathrm{i}$ «промовляння» партії фортепіано: біблійні оповіді - це безмежний простір для тлумачення, 
де велике місце відведено домислюванню. Якщо допустити, включити для себе цей простір відкритих смислів і особистих припущень, може вийти, що характер висловлювань в партії оркестру і соліста куди більш органічно лягає на сюжет іншого діалогу, який і не прийнято називати діалогом у загальному сенсі слова, але «Молінням про чашу», і який, відповідно до, знову-таки, біблійного сюжету, мав місце бути в Гетсиманському саду. Отже, в діалозі (можливому!) Бога-Отця і Сина вже були укладені дві паритетні суті - Бога і людини.

Після виникнення для нас цієї зв'язки музичної форми (не в структурному, а сутнісному сенсі) і біблійного сюжету, де музика вже не просто інтерпретувалася за заданим раніше сценарієм, але виступала інтерпретуючим інструментом біблійного сюжету, ми приступили до промальовування у своїй уяві театралізації, якої так бракувало. Але, як виявилося, iіi вже намалювали до нас (або для нас). I це - вже друге осяяння-підтвердження наздогнало нас у тому місці, де багато концертуючих музикантів шукають натхнення - в картинній галереї, а саме в Третьяковській галереї.

Картина В.Г. Перова «Христос в Гетсиманському саду» [7] - це аж ніяк не «хітове» полотно художника, що кардинально відрізняється від піднесених і звичних художніх образів, які частіше виступають у зв'язці з цим біблійним сказанням - на ній, на відміну від інших, зображений не Бог-Син, який розмовляє, або молиться перед Богом-Батьком, а перш за все людина. Надзвичайно яскраво підкреслено і виведено головним лейтмотивом у цьому полотні те, що Ісусу ніщо людське в цей час не чуже - він у розпачі, в страху і від того просить пронести цю чашу повз нього.

Та емоція, яка передана в тонах і півтонах цієї картини, та приголомшуюча тиша, яка ховається в темно-зелених відтінках ліній, та зневірена смиренність, що передана позою того, хто молиться, знесиленого і полеглого, й утворює характер звучання, в якому починається після могутнього і суворого, «запитуючого» оркестрового вступу партія фортепіано [1, такти 6-13]. Бог-Син, або бог-людина, молиться, майже не маючи надіï, передчуваючи і боячись того кроку, який йому належить зробити. Далі знову оркестр - невблаганний і майже жорстокий у своєму струнному об'ємному tutti. I знову соліст знову просячи і благаючи. Прохання - більш розгорнуто i впевнено проступає в проблиску мажору, який разом із тим тут 
же перекриваються скорботними інтонаціями [1, такти 19-26]. Оркестр і в третьому своєму проведенні непохитний. Короткими репліками із протяжними оборотами мелодії соліст і в третій раз не залишає свого благання [1, такти 28-29; 31-33]. Надія ще ніби б'ється в усе більш і більш коротких відіграшах. Але в них водночас проступає і прийняття неминучого. Остання довга фраза цього третього соло-епізоду вся побудована на пронизуючому спадаючому ході мелодії з верхнього регістру, гармонійне, мелодійне і експресивне напруження якої скорботне до межі [1, такти 34-38]. Три проведення. Три спроби. Це число тут не випадкове. Якщо ми звернемося до відомих нам Євангелій, то знайдемо в Євангеліях від Марка і від Матвія розповідь про триразову молитву Ісуса в Гетсиманському саду [5, 14: 33-42; 6, 26: 36-46]: перший раз Він молиться про відведення від Нього чаші страждань, другий раз виявляє вже пряму покірність волі Божій, втретє Він повторює своє друге моління і повертається до учнів сказати про наближення зрадника.

Якщо ми спроектуємо сенс трьох фраз - трьох прохань Ісуса - на музичні репліки соліста, то отримаємо те саме шукане театралізоване дійство, пронизане майже оперним синтезом мізансцени, слова, музики і декорацій, що знайшло рельєфну наочність.

Після цих трьох епізодів оркестр, або Бог-Отець, пом'якшується. У подальшому висловлюванні соліста ще прорветься пристрасне метання, що виражатиметься в трепетних, що пронизують, трелях і пасажах, однак цей спалах є недовговічним і безцільним. Як влучно висловився про цю «точку» М. С. Друскін: «Але слабшає драматичний порив і знову чуються таємничі загрозливі унісони басів. На фоні застиглих акордів струнних прощальний відгомін стогонів соліста (арпеджірований тризвук мі мінору із затриманим, «болісним» II ступенем - фа-дієз)» [3]. Світло на сцені поступово згасає. Дійство закінчено.

Повернемося тепер до того небувалого контрасту, який являють собою друга і фінальна частина концерту. Вище ми описували те, як «не стикуються» тут музичні «замальовки», які мають корелювати, будучи частинами одного цілого, концертного циклу. Але якщо ми згадаємо, що після «Моління про чашу», а також після подальших сюжетів Голгофи i розп'яття, настало Воскресіння, то ключовим змістом для нас буде строфа вже з Євангелія від Іоанна: «<..> ви будете плакати та голосити, < ..> але сум ваш обернеться в радість!» 
[4, 16: 20]. Якщо слідувати такому трактуванню, що вдасться пояснити собі і те, чому і як з'являється такий фінал після такої другої частини. Форма родно з абсолютно радісним, «живішим за всіх живих» рефреном є нішо інше, як святкування і багаторазове (за кількістю проведень головної теми) твердження, практично маніфест панування світла.

Отже, подібне тлумачення, театралізація дійства - повторимо ще раз, оскільки це принципово важливо для нас - $€$ не просто інтерпретацією музики, але актом інтерпретації певних сюжетів самою музикою - «смислом, промовленим музичним звучанням» [10, с. 43]. Більш того, це не є метою, а засобом. I якщо відволіктися від сюжетної конкретики, пов'язаної з нашим предметом дослідження, то загальним джерелом розкриття подібного сценарного підгрунтя (в техніці прочитання практично будь-яких музичних творів) буде якраз той простір, про заповнення якого йшлося в основній постановці питання. Простір, в якому «живе» пам'ять життя, що включає в себе все різноманіття пережитого, прочитаного, прослуханого, накопиченого як усвідомлено, так і несвідомо, все те розмаїття інформації, що виступає їжею для музичного мислення, що має постійно формуватись.

Окрім вищезазначеного, вагомим є вміння все це вербалізувати, тобто здатність зрозуміти, осмислити і сформулювати емоційний досвід в абсолютно певний прецедентний смисл. Наше розуміння співвідноситься з висловом С.I. Савшинського: «Пошуки вірних слів для вираження знайденого і зрозумілого при аналізі нотного тексту будять думку і не тільки думку. Одночасно вони направляють емоційні відгуки» $[9$, с. 90], таке ж розуміння зустрічаємо в Самойленко в положенні про «роль вербалізації як усвідомлення» [10, с. 56].

Мова про здійснення пошуку особистісних смислів, укладених у прецедентах, що архівуються в пам'яті індивідуума, в результаті чого породжується прецедентний сенс - уже своя власна і цілком обгрунтована точка зору на музичний твір. Прецедентами, що породжують асоціації, відповідно, смисли в цьому випадку для нас виступили:

- опис у різних Євангеліях сюжету «Моління про чашу»;

- трактування цього сюжету в живописі;

- прецедент іншого порядку - збережений у пам'яті епізод iз репетиції Миколи Петрова, де була озвучена особиста концепція виконавського прочитання концерту. 
Іншими словами, працює процес створення прецедентних смислів, які є основою інтерпретації.

Висновки. Прецедентні смисли музиканта ми визначаємо як усвідомлену похідну емоційної пам'яті. Емоційна пам'ять - скарбничка пережитих емоцій, $є$ основою прецедентних смислів, самі ж прецедентні смисли - це відрефлексовані і осмислені емоції (осмислені як в причинах, так і в подальшому їх застосуванні у творчості). Отже, розуміємо їх як такі, що виникають не тільки асоціативно, але й свідомо.

Системоутворюючими елементами концепції народження самобутньої інтерпретації музичного тексту на базі феномена прецедентних смислів $\epsilon$ такі:

- сприйняття та збереження. Народження особистого художнього прочитання-осмислення виконуваної музики починається із запуску акумулятивного процесу: сприйняття і архівації (збереження в пам'яті) якомога більшого числа прецедентів (фактів) особистого зіткнення з будь-якими потенційно цінними джерелами інформації та емоційного досвіду;

- пошук, осмислення і зіставлення. Пошук здійснюється на основі акумульованого досвіду зіткнення з носіями інформації, за допомогою розархівації прецедентних смислів, що архівувалися раніше в пам'яті індивідуума. Осмислення відбувається в процесі пошуку і спровоковано ним. Зіставлення виступає як додатковий інструментарій переробки отриманих знань;

- народження творчого похідного прещедентних смислів, що виникає внаслідок реалізації вище перелічених елементів і виступає підгрунтям створення самобутньої інтерпретації.

Етапи створення прецедентних смислів, що відповідають як процесам архівації, так і розархівації емоційного досвіду, $\epsilon$ найвірнішим шляхом конкретизації музичних уявлень. Описаний процес надзвичайно важливий і працює як метод відходу від суто інтуїтивних елементів прочитання музики до усвідомлено-раціональних. Парадоксальним $є$ те, що відхід цей здійснюється за допомогою накопичення і переробки саме чуттєвого досвіду переживання. Втім, ця парадоксальність проявляється лише зовні, бо при найближчому розгляді йдеться не просто про архівацію та розархівацію чуттєвого досвіду, а й про його інтелектуальне освоєння. Кінцевою метою процесу народження прецедентних смислів будуть видимість, інтелектуалізація прочитання, предметність кожної 
інтонації. У результаті культивується вміння пояснити, «про що» оповідає будь-яка гармонія або мелодійний розворот, i це робить саме виконання інтерпретацією, а питання тлумачення музичного твору зводить у ранг цілком конкретного етапу роботи. Практикуючого виконавця такий шлях здатен привести до абсолютно нового якісного відчуття виконання і 3 плином часу стати певним творчим і педагогічним методом.

\section{СПИСОК ЛІТЕРАТУРИ}

1. Бетховен Л. Партитура концерту для фортепіано с оркестром Соль мажор, оp. 58, Andante con moto. URL: https://imslp.simssa.ca/ files/imglnks/usimg/e/ed/IMSLP01288-Piano_Concerto_No._4_in_G Major,_Op._58-II._Andante_con_moto.pdf (дата звернення: $1 \overline{1} . \overline{06} .2 \overline{0} 20$ )

2. Выготский Л.С. Психология искусства. Москва : Искусство, 1968. $330 \mathrm{c}$.

3. Друскин M. Фортепианные концерты Бетховена. URL: https://beethoven.ru/node/251 (дата звернення: 01.06.2020)

4. Свангеліє від Іоанна. URL: https://allbible.info/bible/sinodal/ joh/16/ (дата звернення: 16.06.2020)].

5. Свангеліє від Марка. URL: https://allbible.info/bible/sinodal/ $\mathrm{mr} / 14$ / (дата звернення: 08.05.2020).

6. Євангеліє від Матвія. URL: https://allbible.info/bible/sinodal/ $\mathrm{mt} / 1$ / (дата звернення: 08.05.2020).

7. Перов В.Г. «Христос в Гефсиманському саду». URL: file:///Users/aleksandra/Desktop/\%D0\%9F\%D0\%B $\%$ D $1 \% 80 \%$ D0\% BE\% D0\%B2.webp (дата звернення: 17.12.2020).

8. Прецедент. Определение понятия. URL: https://ru.wikipedia.org/ wiki/\%D0\%9F\% (дата звернення: 17.12.2020).

9. Савшинский С.И. Работа над музыкальным произведением. Москва - Ленинград : 1964. 185 с.

10. Самойленко O.I. Психологія мистецтва: сучасні музикознавчі проекції : монографія. Одеса : Гельветика, 2020. 236 с.

\section{REFERENCES}

1. Beethoven, L. Score of Concerto for Piano and Orchestra in G Major, op. 58, Andante con moto. Retrieved from: https://imslp.simssa.ca/ files/imglnks/usimg/e/ed/IMSLP01288-Piano_Concerto_No._4_in_G_ Major,_Op._58-II._Andante_con_moto.pdf

2. Vygotsky, L.S. (1968). Psychology of art. Moscow: Art.

3. Druskin, M. Beethoven's piano concertos. Retrieved from: https://beethoven.ru/node/251 [in Russian].

4. The Gospel of John. Retrieved from: https://allbible.info/bible/ sinodal/joh/16/ [in Russian].

5. The Gospel of Mark. Retrieved from: https://allbible.info/bible/ sinodal/mr/14/ [in Russian]. 
6. The Gospel of Matthew. Retrieved from: https://allbible.info/bible/ sinodal/mt/1/ [in Russian].

7. Perov, V. G. "Christ in the Garden of Gethsemane» Retrieved from: file: ///Users/aleksandra/Desktop/\%D0\%9F\%D0\%B5\%D1\%80\% D0\%BE\% D0\%B2.webp

8. Precedent. Definition of the concept. Retrieved from: https://ru.wikipedia.org/wiki/\%D0\%9F\% [in English].

9. Savshinsky, S. (1964). Work on a musical piece. Moscow - Leningrad: Sov. composer [in Russian].

10. Samoilenko, O. (2020). Psychology of art: modern musicological projections: monograph. Odessa: Helvetica [in Ukraine].

УДК 78.01/.072.2+.08/781.68

DOI https://doi.org/10.31723/2524-0447-2020-31-2-14

Бай Сяонань

ORCID: 0000-0003-1018-482X

здобувач кафедри історії музики та музичної етнографіі

Одеської національної музичної академії імені А. В. Нежданової

27539467@qq.com

\section{МУЗИЧНА ТЕМПОРАЛЬНІСТЬ ЯК СПЕЦИФІЧНИЙ ХУДОЖНІЙ ФЕНОМЕН}

Мета дослідження - запропонувати сталі системні критерії вивчення музичної темпоральності шляхом поєднання процесуального та структурного підходів, таким чином - шляхом відкриття взаємозалежності часу та простору у принципах музичної образної логіки. Методологія роботи зумовлюється поєднанням філософсько-естетичного феноменологічного та текстологічного мистецтвознавчого підходів, із залученням систематичного жсанрово-стильового методу. Розвивається психологічний аспект музикознавчих характеристик, що визначається увагою до специфічних рис музичного діяння. Наукова новизна даної статті зумовлюється відкриттям антиномічної природи часу в музиці та притаманного музичній темпоральності, як специфічному художньо-музичному втіленню часу, способу «подвійного відбиття» тих особливостей людського буття, що узагальнюються категорією часу. Пропонується визначення двох основних взаємодіючих способів розумін-

(C) Бай Сяонань, 2020 